


\title{
Iran's criminal policy towards money laundering in the country's \\ banking system
}

\author{
DOI: https://doi.org/10.46398/cuestpol.3969.21
}

Leila Forouzan Far *

\begin{abstract}
Using the documentary research methodology, the aim of the article was to study Iran's criminal policy towards money laundering in its banking system. A number of measures have been taken in the Iranian legal system to combat money-laundering, the most important of which is the adoption of the anti-moneylaundering law in 2007 and its executive regulations in 2009. With the enactment of this law, the crime of money laundering officially entered the Iranian legal system with its own special and independent title. By way of conclusion, it is evident that various governmental and judicial institutions have made the fight against money-laundering one of their main objectives and tasks. Meanwhile, the role of the National Audit Office has also been prominent, and it has made numerous efforts, both nationally and internationally, to identify cases of money laundering, eliminate money laundering and ultimately combat it
\end{abstract} effectively and efficiently.

Keywords: money laundering; economic and financial crimes; elements of the offence of money-laundering; prevention of the crime; criminal policy.

\footnotetext{
Graduated in private law from Allameh Mohaddes Noor University,Noor Iran. ORCID ID: https:// orcid.org/oooo-0002-3947-6925. Email: frozanfar2@yahoo.com

Recibido el 15/03/2021 Aceptado el 21/06/2021
} 


\section{La política criminal de Irán hacia el blanqueo de dinero en el sistema bancario del país}

\section{Resumen}

Mediante la metodología de investigación documental, el objetivo del artículo fue estudiar la política criminal de Irán hacia el blanqueo de dinero en su sistema bancario. En el ordenamiento jurídico iraní se han adoptado varias medidas para combatir el blanqueo de capitales, la más importante de las cuales es la aprobación de la ley contra el blanqueo de capitales en 2007 y su reglamento ejecutivo en 2009. Con la sanción de esta ley, el delito de El blanqueo de dinero entró oficialmente en el sistema jurídico iraní con su propio título especial e independiente. A modo de conclusión se evidencia que diversas instituciones gubernamentales y judiciales han hecho de la lucha contra el blanqueo de dinero uno de sus principales objetivos y tareas. Mientras tanto, el papel de la Oficina Nacional de Auditoría también ha sido prominente, $\mathrm{y}$ ha realizado numerosos esfuerzos, tanto a nivel nacional como internacional, para identificar casos de lavado de dinero, eliminar el lavado de dinero y, en última instancia, combatirlo de manera eficaz y eficiente.

Palabras clave: blanqueo de dinero; delitos económicos y financieros; elementos del delito de blanqueo de dinero; prevención del delito; política criminal.

\section{Introduction}

Money laundering is on top of other criminal activities in the financial sector. This phenomenon is a process during which criminal and illegal activities are placed in legal channels and purified in a seemingly process. Money laundering is a three-step process, the first of which is to sever any direct link between the crime and the proceeds of illicit origin.

The second stage is to hide the rejection of property by conducting transactions and the third stage is to give legal appearance to the property obtained from the crime. Banks are one of the main channels for money laundering for criminals; this is done through three ways of placing illegal income in the financial system and the Chinese layer and integrating it. Such activities are carried out through official banking services, deposits, transfers, and illegal schemes, using bank credits, and the bank's employees or managers may cooperate in some way.

Although banking supervisors around the world do not have the same responsibilities and goals to combat money laundering, the prohibition of abusing the banking system for illegal activities should be one of their 
Leila Forouzan Far
$346 \quad$ Iran's criminal policy towards money laundering in the country's banking system

main responsibilities and goals. Such authorities are obliged to reform their activities, and the capacity of banks to ban operators from using their services must be strengthened. In this regard, training of employees and their familiarity with money-laundering methods and its identification methods and the banking system's policy in dealing with this financial crime have a great impact on the effective fight against this phenomenon.

Overall, It is essential to provide special training to bank employees who are more exposed to criminal money-laundering activities. These individuals must be familiar with the relevant laws and regulations and have the necessary ability to identify and detect suspicious transactions and activities.

\section{The concept of money laundering}

Given the nature of money laundering, which is multidimensional and wide-ranging, it is difficult to provide a precise definition of this crime (Najafi Abrandabadi and Hashembeigi, 1998; Abbasi, 2012) Jeffrey Robinson has interpreted the crime of money laundering as follows: This is like a stone being thrown into a pool; you see the moment the stone enters the water, because the water shakes at that point. When the rock falls, waves are seen for a moment and you can find the point where the rock fell into the water, but the more the stone sinks, the more the water wave disappears until the stone reaches the bottom of the pond and no traces of it remain, and it may be impossible to find the stone. This is exactly what happens with laundered money (Abbasi, 2012).

\section{Legal pillar}

The origins of the fight against illicit wealth must be sought in Article 49 of the Constitution of the Islamic Republic of Iran of course, this does not mean that this principle is considered a manifestation of the fight against money laundering, but this principle can be the basis of the fight against money laundering. In Iranian law, according to Article (2) of the AntiMoney Laundering Law approved by the Islamic Consultative Assembly in 2007, the crime of money laundering has been defined and legislated, which is (Tamanaha, 2014).

- Acquisition, possession, maintenance or use of proceeds of illegal activities with the knowledge that it was obtained directly or indirectly because of a crime.

Conversion, exchange, or transfer of income in order to conceal its illegal origin knowing that it is directly or indirectly caused by the commission of 
the crime or to assist the perpetrator in such a way that he is not subject to the legal effects and consequences of the crime.

Concealment, concealment or concealment of the true nature, origin, source, location, transfer, transfer, or ownership of income obtained directly or indirectly as a result of a crime.

\section{Penalty for money laundering}

The proportion between crime and punishment is one of the principles governing punishments; that is, the legislature in criminalizing the act or intensifying the punishment should anticipate the most appropriate reactions to the crime to have the greatest effect and deterrence the time of execution and in practice. Whenever the purpose of punishment is to make it useful, the legislator must measure the punishment's effectiveness and formulate the reaction of the society in the form of criminal laws in proportion to the criminal behaviour and the damage it has caused to the public order.

The rational approval and execution of punishments and the observance of punishment's proportionality with the crime can be effective in reducing delinquency (Eslamian et al., 2020). The type and amount of punishment is one of the factors that perpetrators usually consider and evaluate when deciding to commit a crime. The criminal is a human accountant, so if the study between profit and loss due to committing a crime is balanced and more in favor of losses and costs, he usually gives up committing a crime; unless he is a risk-taker (Soltanifard et al., 2018).

This highlights the importance of the legislature's duty to ensure the usefulness and appropriateness of money-laundering criminalization. In the case of money laundering, the perpetrators' greatest goal and motivation is to achieve financial benefits. In this crime, the perpetrators usually have a clinical social status; Therefore, it is necessary to determine the punishments that seriously harm their interests (whether financial interests or social status).

The Iranian legislature, regardless of the principle of proportionality between crime and punishment in Article 9 of the Anti-Laundering Law (Siclari, 2016), has determined the punishment for money-laundering:

The perpetrators of money-laundering are sentenced to a fine of a quarter of the proceeds of the crime, in addition to the recovery of the proceeds of crime and the proceeds of the crime, including the principal and benefits obtained and, if not available, the like or its price (Siclari, 2016: 25).

This article of the anti-money laundering law is criticized for not observing the balance between crime and punishment. 


\section{Iran's criminal policy towards money laundering in the country's banking system}

For, first, one of the purposes of punishment is its deterrent aspect, and intimidation has always had a special place in the legislature's choice of punishment. The intimidating aspect of punishment means that future crimes are prevented by imposing punishments on the perpetrators. On the other hand, non-criminals and those who intend to commit a crime are intimidated and do not commit any more crimes, and the perpetrator himself refuses to commit the crime again (Bohoslavsky and Cernic, 2014).

However, it seems that the punishment imposed for the crime of money laundering is not a deterrent and, on the contrary, the imposition of a fine is a great incentive for violators. Because if the payment of this amount is not high for the criminals, and as long as the utility of corruption is higher than the crime, the corrupters will continue to be stronger (Maleki and Rahimi, 2014).

According to the note of the mentioned article, if the proceeds of crime are converted or changed into another property, the same property will be confiscated, and according to Note 2 of the same article, the issuance and execution of a confiscation order and the benefits derived from it are allowed if the accused has not been subject to this sentence in terms of the crime of origin. In fact, these regulations point to the impossibility of enforcing the seizure regulations in cases where the proceeds of crime have been imposed due to the commission of the original crime. Therefore, it cannot be re-recorded. Also, according to Note 3 of Article 9 of the Anti-Money Laundering Law, the perpetrators of the crime of origin will be sentenced to the punishments provided in this law in addition to the prescribed punishments related to the crime if they commit the crime of money-laundering (Siclari, 2016).

Since, according to the fundamental principles of domestic law, the imposition of punishment for the principal offense is not in conflict with the imposition of a penalty for the offense of money laundering; both punishments are imposed if one person commits these two offenses. Whereas part (e) of paragraph 2 of Article 23 of the Convention states: "If the fundamental principles of the domestic law of a Member State so provide, that State may specify that the offenses set forth in paragraph 1 of this article shall not apply to persons who have committed the principal offense" (Born, 1994: 19).

\section{Identify criminal liability for legal entities}

The fact is that today many crimes such as fraud, crimes and violations of corporate law are often committed by individuals and under the auspices of legal entities or a company. Therefore, it is expedient that in addition to the criminal responsibility of the representatives of these persons, at least 
for the execution of financial penalties, especially if the representatives of the company are poor, there should be criminal liability of legal persons.

Thus, under the influence of judicial considerations and criminological facts, the contemporary doctrine agrees with legal persons' criminal liability. Recognizing that groups are always involved in transnational organized crime, these groups can be registered in the government or even as public law entities. Legal entities are a good cover for criminal groups. Mafia gangs formally establish some companies and legal entities to help commit organized crime and launder the proceeds. The need to combat these crimes requires the acceptance of criminal liability by legal persons. This issue is accepted in the mentioned international documents. Considering that in the past, in all international documents and international criminal courts, the procedure has always been to prosecute natural persons and not to accept the criminal responsibility of legal persons, this is a significant and innovative development.

However, in Iranian criminal law, the criminal liability of legal entities has not been accepted yet, and even in cases where the legislator has been in a position to express him, he has not wanted to impose criminal liability on legal entities. For example, in Article 568 of the Islamic Penal Code, the legislator, although in the position of expressing crimes committed by legal entities, has accepted only the criminal responsibility of natural persons (Sadeghi et al., 2012; Iran: Islamic Penal Code, 1991). For this reason, the money-laundering law criminalizes legal entities that commit moneylaundering, regardless of international recommendations in this area. Note 3 of Article 4 of the said law stipulate:

All executive by-laws of the above-mentioned council shall be binding on all relevant natural and legal persons after the approval of the Council of Ministers. The violator will be sentenced to two to five years of dismissal from the relevant service, as the case may be, at the discretion of the administrative and judicial authorities.

\section{Judicial solutions}

The legal solutions that can be enforced in dealing with money laundering are as follows:

\subsection{Facilitate crime detection and proof}

\section{a. Acceptance of criminal records}

One of the most important and innovative solutions supported in international documents to combat money-laundering, overturning the principle of criminal innocence. The principle of innocence is one of the 


\section{Iran's criminal policy towards money laundering in the country's banking system}

basic principles governing the course of criminal proceedings, according to which every innocent person is presumed, and if he is charged with presumption of innocence, the prosecutor's office must prove his guilt. Despite the place that this principle has in criminal matters and governs other principles and rules of criminal law, however, in certain cases of application of this principle of transgression, and despite the fact that the principle is innocence, and the prosecuting authority must prove the material and spiritual elements of the crime, and the accused is not obliged to prove his innocence, the task of presenting the reason is shifted and falls on the accused.

The basis for deviating from the principle of innocence is, in many cases, the very basis that justifies the rule of the principle of innocence in criminal matters.in other words , Just as legal justice requires that the accused be acquitted in the absence of evidence, innocence and innocence, In special cases, where the existence of evidence strengthens the suspicion of committing a crime by the accused, the requirement of legal justice and public interests is the precedence of the principle of guilt over the principle of innocence (Eslamian, et al., 2020).

\section{b. Using informants and special research techniques}

One of the methods proposed in the Palermo Convention to detect and prove organized crime, including money laundering, is the use of informants. Money-laundering research is based on the development of information, including intelligence (Standing, 2010). Educating and training informants is very important in pursuing money laundering. Informants may be airport employees who become aware of the unusual transfer of money in and out of the country. Alternatively, are secret members of the police who gather news in the course of their mission; for example, undercover agents in search of money-laundering services or money launderers who want to exchange illicit money for criminals are replaced as criminals? Alternatively, he may be a criminal himself who has repented and is trying to give his information to the legal authorities.

Given the difficulties in infiltrating criminal gangs and detecting and arresting them, these remorseful criminals' information is very important. Of course, these informants can sometimes report false information as well, in order to mislead the police in finding the trust in the reports. In any case, these criminals have expectations for any cooperation with law enforcement officers. For this reason, Article 26 of the Palermo Convention, entitled "Measures to increase cooperation with law enforcement agencies" was adopted. It also urges member states to take action, to encourage individuals and members of organized crime groups to provide useful information about the details, The nature, composition, structure, location, activities of these groups and their relationships with other groups, crimes committed or may be committed by these groups as well as to provide 
concrete and documented assistance to law enforcement agencies that could deprive criminal groups of material resources or proceeds of crime.

\section{c. Confiscation and confiscation of property}

As mentioned earlier, confiscation has been emphasized in all international instruments as a guarantee of effective performance in money-laundering, and countries have been asked to consider this in their domestic law in response to money-laundering, as a result, it is the duty of the judiciary to sentence the offender to this punishment in order to implement these laws, and in order to carry out this punishment, they should use all the necessary facilities to provide a good financial source while punishing the criminals, which can be spent on fighting crimes. Confiscated property includes property that is directly derived from the commission of a crime or we in return for it.

That is, if this income is consumed or lost in any way, the equivalent will be confiscated from the property of the offender, and if it has been converted or altered into another property, the property shall be confiscated instead of the proceeds (paragraph 3 of Article 12 of the Palermo Convention).This provision ensures that, first, the concealment or replacement or destruction of the same property resulting from the crime does not interfere with the confiscation operation, and secondly, it makes it possible to seize legal property, that is, the offender is liable for the equivalent of property resulting from the crime, even if he has lost the original illegal property.

Appropriable property also includes indirect proceeds of crime. That is, income or other benefits derived from the proceeds of crime or from property to which the proceeds of crime have been converted shall be confiscated in the same way as direct proceeds of crime. The rules also include the confiscation of property, equipment or other items that have been or will be used to commit a crime, and if this income is mixed with the property obtained through legal means, the said property will be confiscated up to the approximate amount of the mixed income.

Therefore, contrary to Iranian domestic law, other perpetrators' property that has nothing to do with the crime cannot be confiscated. Therefore, if a vehicle is dedicated to smuggling, it can be confiscated However, the house or other property of the perpetrator that has nothing to do with the crime and is legally acquired and not used for the crime can't be confiscated (Salimi, 2007).

\section{Methods of Prevention of crime, money laundering}

Prevention is a general concept and refers to a set of actions that are taken to prevent and prevent harmful interactions suffered by the 
Leila Forouzan Far
352 Iran's criminal policy towards money laundering in the country's banking system

individual and the group, such as prevention of work accidents, prevention of youth delinquency and prevention of accidents on the roads, etc. Najafi abrandabadi writes about the word prevention:

The word prevention today in its current and common sense has two dimensions. To prevent means to overtake, to overtake, and to move forward, and to warn, to warn, and to warn. But in preventive criminology, prevention is used in its first sense, that is, the use of various techniques in order to prevent the occurrence of delinquency, the goal is to prevent crime and surpass delinquency (Najafi and Hakimipour, 2018).

In this section, the important strategies of Prevention of crime, moneylaundering are examined:

\subsection{Customer identification}

Customer identification is the identification and verification of customer identity using independent, credible, and reliable information sources, documents and data. Customer identification is divided into two groups of actions including "initial identification" and "complete identification". The purpose of initial identification is to match and confirm the specifications stated by the client with the identification documents and in case of action by the representative or lawyer, in addition to registering the details of the lawyer or representative, the original registration. Full identification also refers to the accurate identification of the customer, including the initial identification items in addition to the recognition of the job status, Field of activity and managers of legal entities, income, education, exact address of residence and work and estimation of the level of financial relations of the client and .... When providing basic services (Aluko and Bagheri, 2012).

\subsection{Maintaining information and records}

Financial institutions should keep records of their domestic and international transactions in such a way that they could respond to requests for information from competent authorities in the shortest possible time. Record keeping as a solution to crime prevention, money laundering is also envisaged in Iranian law. In paragraph (d) of Article 7 of the AntiMoney Laundering Law (2007) (Siclari, 2016). The legislator has obliged the persons, institutions, and bodies subject to this law, according to their type of activity and organizational structure, to keep records related to the identification of the client, records of accounts and operations and transactions for the period specified in the executive regulations. 


\subsection{Report suspicious transactions}

Suspicious operations and transactions are transactions and operations in which individuals suspect that they have money-laundering operations in the possession of information or logical evidence, and logical evidence refers to the conditions and requirements that compel a normal human being to investigate the origin of property and deposits or other related operations (Aluko and Bagheri, 2012). Reporting suspicious transactions as a Prevention of crime, money-laundering solution is also included in the laws of many other countries.

In April 1999, for example, a new anti-money laundering law was enacted in Switzerland, which required banks to report suspicious accounts to the government and then block those accounts. This law also includes non-banking institutions, such as insurance, law firms.

In Iranian law, in paragraph (c) of Article 7 of the Law on Combating Money-laundering, thelegislator is obliged to report the persons, institutions and bodies subject to this law (subject to Articles 5 and 6) according to the type of activity and organizational structure, which includes suspicious transactions and operations to a competent authority designed by the High Council for Combating Money-Laundering. Article 25 (Chapter 4) of the Executive Regulations of the Anti-Money Laundering Law also states: "All employees under the authority of the persons involved are obliged to report suspicious transactions and operations (subject to paragraphs" and "Article 1) without informing the client to the units responsible for combating money-laundering in each device. In the absence of this unit, the highest authority of the person involved will be responsible for receiving reports and taking appropriate action (Eslamian et al., 2020).

Reporting suspicious transactions as a Prevention of crime, moneylaundering solution is also included in the laws of many other countries. In April 1999, for example, a new anti-money laundering law was enacted in Switzerland, which required banks to report suspicious accounts to the government and then block those accounts. This law also includes nonbanking institutions, such as insurance, law firms (Najafi and Hakimipour, 2018). In Iranian law, in paragraph (c) of Article 7 of the Law on Combating Money-laundering, the legislator is obliged to report suspicious transactions and operations to the persons, institutions and agencies covered by this law (subject to Articles 5 and 6) according to their type of activity and organizational structure.

The competent authority designated by the High Council for Combating Money-Laundering. Article 25 (Chapter 4) of the Executive Regulations of the Anti-Money Laundering Law also states: Refer to the units responsible for combating money laundering in each device. In the absence of this unit, the highest authority of the person involved will be responsible for receiving reports and taking appropriate action (Eslamian et al., 2020). 


\subsection{Adopting supervisory measures on financial and banking operations}

Because criminals often launder the proceeds of their criminal activities by using the services and facilities of banks and financial institutions, therefore, one of the most important measures to prevent money-laundering is the establishment of a comprehensive system of internal supervision and control for banks and non-bank financial organizations that provide services for the transfer of money and valuables, which within its competence to prevent and detect all Money-laundering forms will try to maintain records, report suspicious transactions and identify customers, etc.

Adoption of supervisory measures on financial and banking operations has also been considered as one of the solutions for the prevention of crime, money-laundering in Iranian law. Article 18 of the Anti-Money Laundering Law states: Persons subject to the law and the board of directors of nonfinancial trade unions are required to nominate a unit to the Secretariat responsible for combating money laundering, given the size of their organization.

The head of the unit must be selected from the managers of the persons involved. The Secretariat may, if necessary, review the qualifications of the members of the said unit, based on the importance of the unit. Note 1: All eligible persons are obliged to make the necessary arrangements in accordance with the scope of their organization in such a way as to ensure the necessary implementation of the laws and regulations related to the fight against money laundering. Persons covered by paragraph 1 of a regulation are all natural and legal persons subject to Articles 5 and 6 of the law, including the Central Bank of the Islamic Republic of Iran, banks, financial and credit institutions, stock exchanges, insurance companies, central insurance, loan funds. Al-Hasna, charities and municipalities, as well as notaries, lawyers, auditors, accountants, forensic experts, and statutory inspectors (Abbasi, 2012).

\subsection{Training the staff of the institution to identify and deal with money laundering}

Training staff to identify and combat money-laundering Staff training and familiarity with money-laundering methods and methods of identifying it, as well as the institution's policy in dealing with this financial crime, has a great impact on the effective fight against this phenomenon. It is essential to provide special training to those employees of the organization who are more exposed to criminal money-laundering activities. These individuals should be familiar with the relevant laws and regulations and have the necessary ability to identify and detect suspicious transactions and activities. In other words, the officials of an institution should teach the 
methods of dealing with money laundering to the employees of the parts of the institution that are exposed to this phenomenon. These trainings should include methods for identifying suspicious transactions, related rules and regulations, and reporting requirements.

The institution's policy in the fight against money laundering should be in the form of staff waste. In general, financial institutions need to ensure that their employees are aware of their role in combating money laundering. In addition, the institution should identify those staff that need more periodic training. Apart from the group of employees who are particularly engaged in the fight against money-laundering, the other units of the institution that need training are: administrative and financial units, accounting and auditing units, credit department, security, inspection and complaints department and department Legal. Staff training may be done through a variety of executive activities, including lectures, training videos, network and computer training, or other methods. In addition, the distribution of reports and training booklets is very effective in training all employees or a specific group of them. The development of the training program of the institute can be entrusted to the legal, auditing and human resources departments, and the institutes are obliged to keep the documents related to their educational activities.

Financial institutions should tailor anti-money laundering chapters and training materials to their activities. To this end, topics such as customer identification methods, suspicious activity criteria, reporting principles and regulations, especially in foreign exchange transactions, how to move financial documents and money-laundering criminal and civil penalties, should be included in the chapters and training materials. Article 35 of the By-Laws of the Anti-Money-Laundering Law of Iran states: All eligible persons are obliged, in cooperation with the Secretariat, to make the necessary arrangements for the establishment of training courses at the beginning of the service and during the service of their subordinate staff. These courses should be in order to get acquainted with the law, regulations and related instructions, how money launderers operate and especially the latest tricks of money launderers in using the services of persons involved and how to eliminate the criminal origin. It is necessary to complete the mentioned courses in order to continue the service of the employees of the persons involved in the relevant jobs, and the records of the mentioned courses must be recorded in the personnel file.

\subsection{Control and supervision over foreign currencies}

Currency control policies should be used with sufficient caution to combat money-laundering, because this policy is like a double-edged sword, which on the one hand makes it difficult for money launderers to transfer money, and on the other hand, the implementation of this policy leads to 
Leila Forouzan Far
356 Iran's criminal policy towards money laundering in the country's banking system

the creation of parallel markets and a black market, can easily be exploited by money launderers. Therefore, instead of retreating and restricting their financial and currency systems, governments need to take measures to be at the forefront of financial markets and to monitor foreign exchange transactions. One of these methods is the use of regulatory methods to prevent money laundering by government officials. Another way is to give anti-money laundering training to bank and exchange staff. The technical assistance of the International Monetary Fund can also be used for this purpose.

\subsection{International cooperation to combat money laundering and use the experiences of other countries}

As we know, Iran is at the beginning of the fight against money laundering, and it is necessary to gain enough experience in this regard. That is why it is necessary to use the experiences of countries that have fought this crime for many years and have achieved useful results. In Iranian law, in Article 37 of the Anti-Money-Laundering Law, the legislator has made the exchange of information to international organizations and institutions, as well as the collection and acquisition of international experiences, the duties of the Secretariat in the Ministry of Economic Affairs and Finance (Aluko and Bagheri, 2012).

The signatories of the Merida Convention state in Article 14, paragraph 4, of the Merida Convention that States Parties are required to use initiatives of regional, international, and multilateral organizations against money laundering (Ayyoub, 2019). Article 5 also states that Member States shall endeavour to expand global, regional, sub-regional and bilateral cooperation between judicial, law enforcement and financial regulators to combat money laundering. As can be seen, international cooperation to combat money laundering is enshrined in both Iranian law and the Merida Convention as a preventive measure against money laundering.

\subsection{Supervising the property and assets of government officials and officials}

Another effective way to prevent crime, money laundering, is to monitor the property and assets of government officials. Supervision of property and assets means monitoring the legitimacy of their property. This means that the means of owning property must be based on legal and sharia rules and criteria, and individuals must not have acquired their property illegally or illegally according to the situations and opportunities provided to them due to their tenure. This indirect approach to money laundering requires that high-ranking government officials and officials, in accordance with the law, submit a list of their property and assets to the agency or institution that is required by law to deal with these matters within specified times (Fakher et al., 2018). 


\subsection{Preventing the creation of virtual banks}

Sincefinancial and monetary exchanges are an integral part of commercial exchanges, in today's world, and especially in developed countries, along with the expansion of the volume of electronics due to extensive developments in ICT, monetary and financial institutions have also found to support, and E-commerce facilitation should make extensive use of ICT. That is why electronic payment and exchange systems have been evolving over the last few decades. Meanwhile, banks, as monetary intermediaries, have to move to e banking and offer new financial services in all new areas, including e-commerce, and this attitude is the basis for the formation of virtual banks. The purpose of virtual banking is to use advanced software and hardware technologies based on network and telecommunications to exchange resources and financial information of customers electronically, which can eliminate the need for physical presence of customers in bank branches.

The use of centralized computer systems, no time and space constraints for banking operations, high security and the ability to track banking operations and increase speed and efficiency, are features that make the necessity of establishing virtual banks in today's world inevitable (Aluko and Bagheri, 2012).

\section{Conclusion}

In general, money laundering is any act or attempt to conceal or alter the identity of illicit income in such a way that it appears to have originated from legal sources. In other words, money laundering is the process by which the shape, origin, characteristics, type, beneficiaries or final destination of contaminated money changes. Measures taken in advanced financial markets to identify and prosecute money-laundering cases have shifted criminal activity to less developed markets (in terms of the financial system). money-laundering generally consists of three basic steps: placement; Injecting dirty money into the monetary and financial system of the second stage of the porcelain layer; Isolation of the relationship between illicit income and their source or existing activities and the third stage of integration; Giving legal appearance to the wealth from illegal income. Two different perspectives on money laundering, the European perspective, and the American perspective, can be identified.

The European approach leaves banks and other financial institutions free to assess suspicious cases, if such matters relating to money-laundering operations are notified to the competent authorities. On the other hand, the American attitude forces these institutions to disclose information about 


\section{Iran's criminal policy towards money laundering in the country's banking system}

any transfer or trade of more than ten thousand dollars. In general, in Iran, providing the necessary legal, regulatory and executive framework to identify and block the channels of infiltration of dirty money into the official financial network of the national economy is of fundamental importance.

In an intelligent anti-money laundering system, there are several independent agents, each of which acts on its own duty and interacts with other agents to identify suspicious money-laundering activity, so that they can carry out the activity that has Detect money-laundering risk and automatically generate a suspicious activity report on money-laundering.

Now, considering that Bank Melli Iran has a large volume of banking transactions in the country and considering the benefits of intelligent antimoney laundering system, by providing suggestions for localization of this system, tracking, and detecting the activities of money launderers in all transactions. Financial transfers, its use in the National Bank of Iran and the country's banking system were suggested. However, the Iranian legislature in the law against money-laundering and its executive regulations have provided solutions in accordance with the Palermo Convention for the prevention of crime, money-laundering and combating it, including customer identification, record keeping and information , Reporting suspicious transactions, establishing a financial information unit, adopting regulatory measures on financial and banking operations, training the staff of the institution to identify and deal with money-laundering, and so on.

However, as expected, the new preventive measures specific to this emerging criminal phenomenon and envisaged in the Merida Convention, such as the prohibition of the establishment of virtual banks, have not been adopted in the anti-laundering law and it is appropriate that the legislature Take action to fill this gap.

\section{Bibliographic References}

ABBASI, Molaei. 2012. Money laundering in the Iranian law. Armane Elem Publications. Tehran, Iran.

ALUKO, Ayodeji; BAGHERI, Mahmood. 2012. "The impact of money laundering on economic and financial stability and on political development in developing countries: The case of Nigeria" In: Journal of Money Laundering Control. Vol 15, No. 4, pp. 12-31.

AYYOUB, Talebzadeh. 2019. «Transparency In Merida Convention (Uncac) And Comparison With Iranian Law With Respect To Act Of Improvement Of Health Of Administrative System And Fighting Against Corruption.» In: Фундаментальные и прикладные исследования в современном мире. Vol. 26, No. 1, pp. 114-128. 
BOHOSLAVSKY, Juan Pablo; CERNIC, Jernej Letnar, (Eds.). 2014. Making sovereign financing and human rights work. Bloomsbury Publishing. London, United Kingdom.

BORN, Gary B. 1994. «The Hague Evidence Convention Revisited: Reflections on Its Role in US Civil Procedure.» Law and Contemporary Problems. Vol. 57, No. 3, pp. 77-102.

ESLAMIAN, Majid; ABASSI, Asghar; ESMAILI, Mehdi. 2020. "Investigating educational dimensions of the fight against the financing of terrorism in international criminal law in law textbooks" In: Revista Conrado. Vol 16, No. 76, pp. 101-105.

FAKHER, Hossein-Ali; ABEDI, Zahra; AHMADIAN, Majid; SHAYGANI, Bita. 2018. "Comparative Examine the Impact of Financial Development (Based on Money Marketand Capital Market) in the Intensity of Economic Growth Effects on the Environmental Performance" In: Environmental Researches. Vol. 9, No. 17, pp. 133-146.

IRAN: ISLAMIC PENAL CODE. 1991. Available Online. In: https://www. refworld.org/docid/518a19404.html. Consultation date: 11/12/2020.

MALEKI, Atefe; RAHIMI, Farshad. 2014. "Study of accountants' performance to combat money laundering" In: European Online Journal of Natural and Social Sciences: Proceedings. Vol. 2, No. 3, pp-2211-2219.

NAJAFI ABRANDABADI, Ali Hussein; HASHEMBEIGI, Hamid. 1998. Criminology encyclopedia. Shahid Beheshti University. Tehran, Iran.

NAJAFI, Banafsheh; HAKIMIPOUR, Nader. 2018. "Neutrality of Money in Iran's Service Sector” In: The Economic Research. Vol. 18, No. 3, pp. 5778.

SADEGHI, Amroabadi B; GOOGERDCHIAN, Ali; SHAHBAZI, Nima. 2012. Empirical analysis of money laundering shocks on economic growth, government expenditure and income inequality in Iran In: Strategic Research On Social Problems In Iran. Vol. 1, No. 1, pp. 97-117.

SALIMI, Sadegh. 2007. "Human Trafficking And Combatting It In Iranian Criminal Law” SOCIAL WELFARE. Vol. 7, No. 26, pp. 265-286.

SICLARI, D. (Ed.). 2016. The new anti-money laundering law: First perspectives on the 4th European Union Directive. Springer.

SOLTANIFARD, Hosein; MALMEIR, Mahmood; ALIPOUR, Hasan. 2018. "Economic Crimes Criminal Procedure; The Connection between Substance and Process" In: Journal of Legal Studies. Vol. 10, No.3, pp. 159-194. 
Leila Forouzan Far

360 Iran's criminal policy towards money laundering in the country's banking system

STANDING, André. 2010. Transnational Organized Crime and the Palermo Convention: A Reality Check. International Peace Institute. New York, USA.

TAMANAHA, Brian. 2014. "The third pillar of jurisprudence: social legal theory" In: Wm. \& Mary L. Rev. No. 56, pp. 2235-2240.

UNITED NATIONS. 2018. United Nations Convention against Transnational Organized Crime and the Protocols Thereto (The Palermo Convention). Available online. in: https://www.unodc.org/unodc/en/organizedcrime/intro/UNTOC.html. Date of consultation: 08/09/2020. 
Vol. 39 N $^{\circ} 69$

Esta revista fue editada en formato digital y publicada en julio de 2021, por el Fondo Editorial Serbiluz, Universidad del Zulia. Maracaibo-Venezuela 